\title{
Therapeutic activity of sarpogrelate, and dopamine D2 receptor agonists on cardiovascular and renal systems in alloxan-induced diabetic rats
}

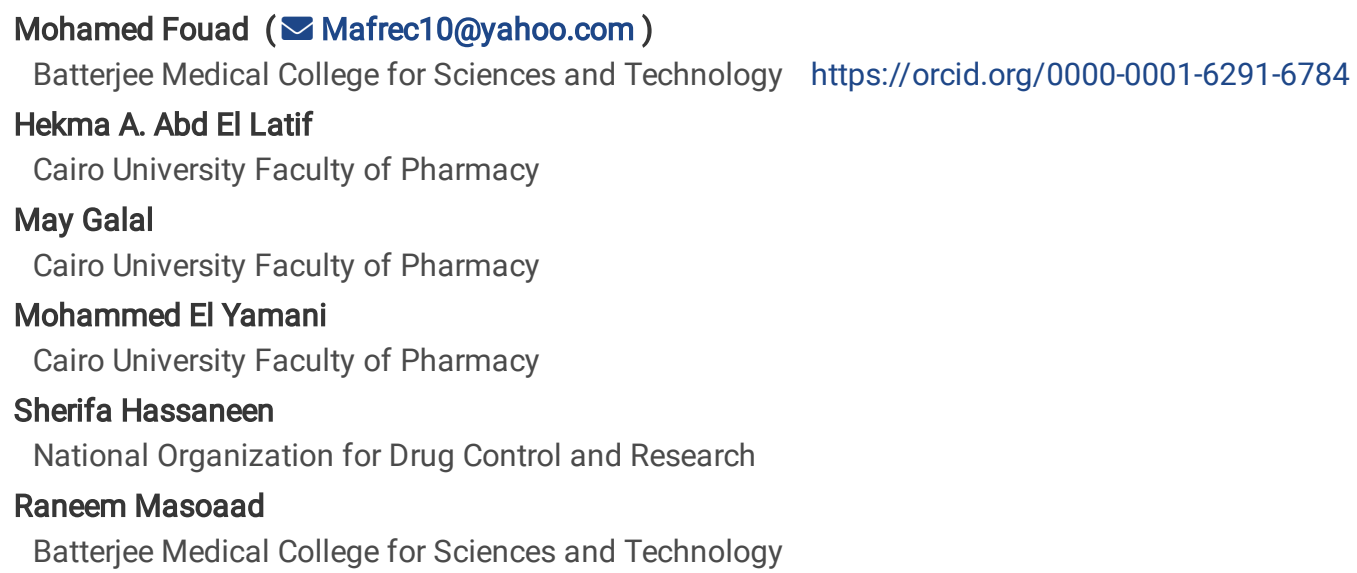

Research article

Keywords: Cardiovascular, diabetic nephropathy, myocardial injury, TNFa1, Dopamine receptors

Posted Date: September 14th, 2020

DOl: https://doi.org/10.21203/rs.3.rs-44926/v2

License: 두 (i) This work is licensed under a Creative Commons Attribution 4.0 International License. Read Full License 


\section{Abstract}

Background: The investigation aims to represent the activity of sarpogrelate, a particular 5-HT (2A) receptor blocker, in reducing myocardial injury prompted by extended haul utilization of $D_{2}$ agonist drugs in diabetic rats. Dopamine $D 2$ agonists are notable medications in the treatment of Parkinsonism, hyperprolactinemia, and hyperglycemia. An affiliation showed between the enlistment of myocardial injury ailment and long term treatment with dopamine $\mathrm{D}_{2}$ agonist drugs identified with the partial initiation of 5-HT 2a receptors.

Methods: Both bromocriptine and cabergoline were managed independently and combined with sarpogelate for about a month to diabetic nephropathy rats. Both tail-cuff blood pressure and BGL were recorded weekly. For all animals, kidney hypertrophy index, serum creatinine, blood urea nitrogen, alanine transaminase, and aspartate transaminase levels were measured after one month of treatment. The severity of the cardiac injury was assessed by the estimation of LDH-1, cardiac troponin I, and TNFa. Triphenyl tetrazolium chloride staining method used to determine experimental myocardial infarction (MI) size.

Results: Bromocriptine and cabergoline created a significant reduction in BGL, BP, and kidney hypertrophy index in diabetic nephropathy rats. Administration of bromocriptine, cabergoline, alone, or in combination with sarbogrelate fundamentally diminished blood concentrations of ALP, AST, urea, and creatinine. Bromocriptine and cabergoline alone showed noteworthy ascending of LDH-1, Troponin I, and TNFa1 levels in the serum $(p<0.05)$. Paradoxically, utilizing bromocriptine and cabergoline with sarpogrelate treatment altogether diminished the degree of the myocardial biomarkers in the serum. A mix of bromocriptine or cabergoline with sarpogrelate diminished the level of the myocardial infarct size in the heart assessed utilizing the TTC staining method.

Conclusions: The examination exhibited that both bromocriptine and cabergoline could be utilized safely in blend with sarpogrelate for a long duration of treatment for diseases like hypertension and diabetes.

\section{Background}

Regarding various diabetes progress complications, diabetic nephropathy is the foremost well-known renal difficulty and the ultimate source of end-stage renal disease. The later phases of diabetic nephropathy define glomerulosclerosis. It was represented by transforming growth factor- $\$ 1$ overexpression, extracellular matrix deposition, and glomerular structure loss [1]. Hyperglycemia is the primary factor for the progress of diabetic nephropathy [2]. It has been demonstrated in several in vitro studies of STZ-induced diabetic nephropathy where serious glucose-induced renal damage is claimed to excessive production of reactive oxygen species (ROS) under hyperglycemic conditions [3, 4, 5]. Bromocriptine is a sympatholytic dopamine D2 agonist that has been approved for treating type 2 diabetes without risk of hypoglycemia because there is no insulin secretion. Supported previous studies stated bromocriptine administration believed to strengthen low hypothalamic dopamine levels and inhibit excessive sympathetic tone within the central system, leading to a reduction in post-meal plasma glucose levels because of enhanced suppression of hepatic glucose production [6, 7]. Agonists working on dopamine D2 receptors can lower hypertension sign by inhibition of $\mathrm{Na} / \mathrm{k}$ ATPase activity, vasodilation, and sympathetic nerve activity inhibition. Bromocriptine may secure against I/R injury of the kidney utilizing p44/42 mitogen-initiated protein kinase actuation [8] and preventing chronic nephropathy [9].

Conversely, the bromocriptine-actuated hypotension was wholly nullified by pretreatment with metoclopramide, a dopamine D2 receptor antagonist that crosses the barrier [10,11]. However, D2 agonists' use is often related to cardiovascular complications, including hypotension and myocardial disorder. There is an identified relationship between the utilization of D2-like R agonists in patients with Parkinson's disease and cardiopathy, especially in the early phase of therapy [12]. D2 receptors are pleiotropic receptors having multiple effects in that activating them inhibits adenylyl cyclase, resulting in inhibition of voltage-gated calcium ions and activation of potassium conductance [13]. Early studies suggested that the use of D2 receptor agonists resulted in a reduction in pituitary tumor mass [14].

It was demonstrated that long term use of bromocriptine therapy was associated with an increased risk of developing heart disease, which occurred in a cumulative dose-dependent treatment [15]. Dopamine D2 receptor agonists are classified as ergot dopamine D2 agonists and non-ergot D2 agonists. Bromocriptine and cabergoline (ergot derivative) are related to valvular cardiopathy since the two drugs have both dopamine D2 and serotonin 5-HT (2A) receptors agonistic activities. Pramipexole (non-ergot derivative) shows few incidences of heart disease onset since it does not affect $5-\mathrm{HT}(2 \mathrm{~B})$ receptors $[16,17,18]$. Both sarpogrelate and ketanserin (selective $5 \mathrm{HT} 2 \mathrm{a} / 2 \mathrm{~b}$ antagonists) constrict cardiac brokenness, infarct size, and changes within the electrocardiogram because of myocardial injury. Likewise, these outcomes bolster the view that serotonin and 5-HT (2A) may augment the harmful impacts of ischemic injury within the heart [19, 20]. Sarpogrelate found to possess beneficial impacts in peripheral vascular sickness, restenosis after coronary stenting, pneumonic hypertension, intense and relentless myocardial localized necrosis [21]. The current study aims to identify the possible protective effect of sarpogrelate, a 5-HT (2A) receptor blocker, associated with cumulative use of D2 agonist drugs therapy on cardiac and renal functions in the diabetic nephropathy model of rats. 


\section{Materials And Methods}

\section{Materials}

Sarpogrelate was obtained from Shanghai Linebon Ltd. Shanghai, China. Bromocriptine was from Novartis, Italy. Cabergoline was purchased from Pfizer, Italy. Domperidone was purchased from Jamjoom pharmaceutical company, KSA. Alloxan was obtained from Sigma-Aldrich (St Louis, MO, USA). Urea; Creatinine; Alkaline Phosphatase; Aspartate Aminotransferase Activity; LDH-1 assay kits; and TNF alpha ELISA Kit were obtained from Abcam company. Troponin I test kit was obtained from Encode Medical Engineering Company, Jeddah, KSA. 2,3,5Triphenyltetrazolium chloride was obtained from Gold Biotechnology, USA.

\section{Animals}

Forty-two Wister albino male rats 5-7 weeks of age weighing 150-200 g were obtained from the animal house of Batterjee medical college, Jeddah, KSA. The animals were housed three per cage under controlled standard laboratory conditions in monitored ventilated cages and spontaneously given food and water. The ethical committee of research of Batterjee medical college approved the steps of the investigation. Tutelage was taken, particularly with relevant housing conditions, to avoid or minimize the animals' discomfort. The animals were kept on solid floored cages with a deep layer of sawdust, and the cages were changed daily. Data were coded prior to analysis so that the treatment group cannot be identified before analysis is completed. At the end of the study, all animals were euthanized by thiopental (intravenous injection, $150 \mathrm{mg} / \mathrm{kg}$ ) for tissue collection.

\section{Induction of diabetes by alloxan}

Alloxan monohydrate was dissolved in sterile normal saline. Diabetes was induced in 30 rats (150-200 g) by a single intraperitoneal injection of alloxan (5\%) $150 \mathrm{mg} / \mathrm{kg}$ b.w. The rats kept fasting for $12 \mathrm{~h}$ before the injection of alloxan. Fasting plasma glucose was measured in blood samples collected from the tail vein. The rats which showed a plasma glucose level of $200 \mathrm{mg} / \mathrm{dl}$ or more were considered diabetic and taken in the study [22].

\section{Experimental design}

Tests took place four weeks after the induction of diabetes. The diabetic rats divided randomly into six diabetic groups and one healthy control group, each group of 6 rats. The sampling calculation was done based on the resource equation method [23]. Once there was a stable rising in the urea and creatinine levels in the blood, drugs were injected once daily for one month.

1. The normal control group (Saline, IP)

2. Diabetic control group (Saline, IP)

3. Diabetic group treated with bromocriptine (4 mg/kg b.w, IP) [24]

4. Diabetic group treated with cabergoline $(0.6 \mathrm{mg} / \mathrm{kg}$ b.w ,IP) [25]

5. Diabetic group treated with sarpogrelate (50 mg/kg b.w, IP) [26]

6. Diabetic group treated with a combination between bromocriptine and sarpogrelate at the same doses.

7. Diabetic group treated with a combination between cabergoline and sarpogrelate at the same doses.

\section{Determination of blood glucose level}

Blood glucose levels were tested on the $7^{\text {th }}, 14^{\text {th }}, 21^{\text {th }}$, and $28^{\text {th }}$ days from the beginning of the treatment. One millimeter of its end cut and a drop of blood was used for blood glucose tests using an advanced glucometer (Roche, USA). The accuracy of glucometer was checked with the O-toluidine method [27].

\section{Blood Pressure Recording}

Basal blood pressure was measured employing tail-cuff non-invasive blood pressure recorder apparatus (Ugobasile instruments, Italy). The measurement of the mean systolic blood pressure for each group of rats was done once time weekly for one month.

Each rat was placed in an exceeding restrainer, and an appropriate cuff sensor mounted on its tail and warmed to about $33-35^{\circ} \mathrm{C}$. The tail cuff was inflated to a pressure above $200 \mathrm{mmHg}$, systolic blood pressure; diastolic blood pressure was measured directly by the tail-cuff and pulse sensor two hours after treatment of drugs [28]. 


\section{Estimation of liver \& kidney functions}

At the end of the study, the blood sample was withdrawn through the retro-orbital venous plexus method, kept at $37^{\circ} \mathrm{C}$ for 30 min, and centrifuged at $4^{\circ} \mathrm{C}, 3000 \mathrm{rpm}$ for $10 \mathrm{~min}$. Then the separated serum was stored at $-20^{\circ} \mathrm{C}$ for various biochemical analyses. Alkaline phosphatase and aspartate aminotransferase activities were determined using the method described by King and King (1954) [29]. The procedure of Tietz et al. (1994) [30] was used to determine serum creatinine concentration, while the serum urea concentration was determined by the method of Kaplan (1965) [31]. After the end of the study, all of the rats were sacrificed. The kidneys samples were collected, washed with normal saline, and weighed. The kidney hypertrophy index was calculated by determining the kidney weight and body weight ratio $(\mathrm{g} / \mathrm{g}) \times 10^{3}$.

\section{Estimation of serum biomarkers of myocardial injury}

The severity of the cardiac injury was assessed by estimating lactate dehydrogenase (LDH-1) and cardiac troponin I (cTnl) in serum. LDH-1 and troponin levels were analyzed by spectrophotometric methods using commercially available diagnostic kits consistent with the methods of Nieland [32].

\section{Serum TNF- $a$ concentration}

Serum TNF-alpha cytokines level was identified by the ELISA technique using a quantitative sandwich enzyme immunoassay technique (Abcam Company). The test was done according to the company's instructions. The ELISA reader's optical density at 405nm was immediately calculated and applied on a standard curve to sort out the cytokines' concentration.

\section{Evaluation of Myocardial Infarct Size by TTC}

For assessment of the myocardial infarcted area, the hearts were removed, washed in phosphate-buffered saline, frozen, and stored at $-20^{\circ} \mathrm{C}$. The frozen hearts were sliced into $1 \mathrm{~mm}$ sections along the long axis from apex to base. Triphenyl tetrazolium chloride (TTC) staining is accustomed to assess myocardial tissue viability and determine myocardial infarction size. The tissue slices were incubated in $1 \%$ TTC PBS solution, $\mathrm{pH} 7.4$, at $37^{\circ} \mathrm{C}$ for $20 \mathrm{~min}$. Tissues were fixed in $10 \%$ PBS-buffered formalin overnight at $2^{\circ} \mathrm{C}-8^{\circ} \mathrm{C}$. Either side of every TTC-stained tissue slice was photographed with the photographic camera to differentiate the red-stained viable and white-unstained necrotic tissues [33]. Digital photographs are downloaded to a computer. Areas stained in white and red were measured using SigmaScan software (SPSS Science) in trace-measurement mode. That mode was wont to measure either the ischemic or the infarcted areas, which may be a sum of calibrated pixels during a defined region. This was done manually by drawing an image layer on the photograph [34]. The infarction size percentage was calculated using the following equation:

The percentage of Infarct volume $=$ Infarct volume $/$ Total volume of slice X 100

\section{Statistical analysis}

The data and statistical analysis done comply with the recommendations on experimental design and analysis in pharmacology [35]. The results expressed as mean \pm SE. The significance of the differences between the values were performed by a one-way ANOVA test and Dunnett's Multiple Comparison Test using GraphPad Prism software. $\mathrm{P}<0.05$ was considered to be a significant difference.

\section{Results}

\section{Estimation of blood glucose levels}

The diabetic control group showed a significant increase in BGL compared to the healthy control group. On repeated administration of the bromocriptine $(4 \mathrm{mg} / \mathrm{kg})$, cabergoline $(0.6 \mathrm{mg} / \mathrm{kg})$ individually or in combination with sarbogrelate, a significant $(\mathrm{p}<0.05)$ decrease in blood glucose by time was observed compared to the diabetic control group throughout the four weeks of treatment (Table 1).

\section{Kidney hypertrophy index}

The results showed that the kidney hypertrophy index significantly increased in the diabetic group of rats compared with the normal control rats. However, the index was markedly reduced by both bromocriptine and cabergoline treatment, even individually or mixed with sarpogrelate (as seen in Table 2). There is no effect of using sarpogrelate on the diabetic kidney index.

\section{Hemodynamic Parameter (Antihypertensive activity)}


Alloxan-induced diabetes in rats showed a significant rise in blood pressure after three weeks from the induction of diabetes. Daily oral administration of bromocriptine and cabergoline individually or in combination with sarpogrelate showed a significant decrease in the systolic blood pressure in third week and fourth week of treatment (Table 3). There is no effect of sarpogrelate on BP in diabetic rats.

\section{Estimation of Liver and kidney Functions:}

The serum levels of AST, ALP, urea, and creatinine as an indicator of liver and kidney functions are recorded in table 4. Data revealed that the diabetic control group had a significant increase in the previous biomarkers' serum concentrations compared to the healthy control rats. Daily administration of bromocriptine, cabergoline even alone, or in combination with sarbogrelate significantly decreased serum concentrations of the previous biomarkers compared to the positive control of diabetic rats. There is no marked effect of sarpogrelate treatment on the previous biochemical indicators in the diabetic rats.

\section{Myocardial biomarkers}

Animals treated with bromocriptine and cabergoline for one month in doses $10 \mathrm{mg} / \mathrm{kg}$ and $0.6 \mathrm{mg} / \mathrm{kg}$ respectively displayed significant elevation of LDH-1 activity in the serum. By contrast, using a combination of bromocriptine and cabergoline with sarpogrelate treatment significantly decreases the level of the biomarkers in the serum were observed. The results in table 5 indicated that the qualitative test of the troponin I reagent kit showed only positive results with bromocriptine and cabergoline treated groups. The results of the ELISA test indicate that the expression levels of TNF-alpha 1 in the diabetic rats' groups treated with bromocriptine or cabergoline individually were significantly higher comparing to the diabetic control rats. The groups of combinations between bromocriptine and cabergoline with sarbogrelate showed lower TNF-alpha 1 expression levels than the groups treated with bromocriptine or cabergoline individually (Table 5).

\section{Evaluation of myocardial injury}

Myocardial infarction size was used as an indicator of the progress of the myocardial injury. The hearts of rats treated with bromocriptine 4 $\mathrm{mg} / \mathrm{kg}$, and cabergoline $0.6 \mathrm{mg} / \mathrm{kg}$ showed a significant increase in risk area infarction. By contrast, the combination of bromocriptine or cabergoline with sarpogrelate $(50 \mathrm{mg} / \mathrm{kg}$ ) reduced the percentage of the myocardial infarct size (Figures 1A, 1B).

\section{Discussion}

Both bromocriptine and cabergoline induced hypoglycemic activity may be due to enhanced suppressive hepatic glucose production [36]. The exact mechanism of action as antidiabetic is not entirely identified; bromocriptine decrease hepatic production of glucose, increase glucose transporter production, or increase or mimic glucagon-like peptide-1 activity [37]. Its contribution to hypoglycemia may be due to adjustments in the neural control of seasonal and patterns of food intake and nutrient storage [38]. Bromocriptine was approved by the Food and Drug Administration (FDA) in May 2009 for the treatment of type 2 diabetes.

In the present study, diabetic nephropathy is the most common cause of renal complication and the leading of hypertension. Both bromocriptine and cabergoline showed a marked antihypertensive activity, which agrees with some previous reports [39, 40]. This action is related to dopamine D2 receptors acting drugs can lower the blood pressure by inhibition of $\mathrm{Na} / \mathrm{k}$ ATPase activity, vasodilation, and inhibition of sympathetic nerve activity. Both bromocriptine and cabergoline induced a marked improvement in the kidney function by decreasing urea and creatinine serum levels. The pharmacological pathways that explain this effect have not been sufficiently determined. The result agrees with some of the previous studies suggesting that the development of therapies directed to increase renal D2 receptor expression/function may provide novel and practical approaches to treating renal injury [41].

The high noted adverse effect of bromocriptine and cabergoline on the heart is represented in myocardial injury and infarction approved in the present study by using relative overdoses for a month of treatment manner. The action may be related to dopamine D2 and serotonin 5HT (2A) receptors agonistic properties, increasing the heart pumping rate. It has been reported that both bromocriptine and cabergoline (ergot derivative) have been associated with heart disease since the two drugs have both dopamine D2 and serotonin 5-HT (2A) receptors agonistic properties $[17,18]$. It is hypothesized that the $5-\mathrm{HT} 2 \mathrm{~A}$ receptor is a common contributing factor underlying aspects of vasoconstriction and cardiovascular disorders [42] and vasodilation through activating nitric oxide (NO) synthase (NOS) via serotonin 5-HT (1B) receptors in endothelial cells, possess different effects on regulating vascular tone. These facts lead to consider that sarpogrelate, a 5-HT (2A) receptor blocker, may increase coronary blood

flow via either attenuation of vasoconstriction through $5 \mathrm{HT}(2 \mathrm{~A})$ receptor blockade or of vasodilation by relative stimulation of NOS through 5HT1B receptor [43].

According to the current observed data, the combination of bromocriptine and cabergoline with the new chemical agent sarpogrelate (selective $5 \mathrm{HT} 2 \mathrm{a} / 2 \mathrm{~b}$ antagonists) decreases the adverse effects of these two drugs on the heart. The protective effects of sarpogrelate on 
myocardial tissue were approved by its ability to decrease the secretion of myocardial biomarkers. As shown by decreasing LDH-1, Troponin I, and TNF alpha 1 during the treatment of bromocriptine and cabergoline. Sarpogrelate attenuates cardiac dysfunction, infarct size; these results support the view said that serotonin and $5-\mathrm{HT}(2 \mathrm{~A})$ might contribute to the harmful effects of ischemic injury in the heart. Regarding the biochemical study, sarpogrelate drug can be considered a safe drug on liver and kidney functions.

\section{Conclusions}

According to the given study, both bromocriptine and cabergoline can be used safely in combination with sarpogrelate for the treatment of many diseases like hypertension, diabetes, and Parkinsonism. Thus, we hypothesize that sarpogrelate deserves additional experimental and clinical research related to cardiovascular diseases.

\section{Abbreviations}

ALT: Alanine Aminotransferase

AST: Aspartate Aminotransferase

TNF: Tumor necrosis factor

TTC: Triphenyl tetrazolium chloride

LDH: Lactate dehydrogenase

TTC: Triphenyl tetrazolium chloride

5HT: 5- hydroxytryptamine

ELISA: Enzyme-linked immunosorbent assay

\section{Declarations}

\section{Ethics approval and consent to participate:}

The study was approved in December 2019 by the ethical committee of research of Batterjee medical college. The committee consists of four people. The research protocol and the study plan were submitted. The committee held a comprehensive discussion of risks and benefits before reaching the approval conclusion. During the study, the research coordinator of the ethics committee updated the progress of the research. In addition, the research experiments on animals followed the guidelines of the experimental animals' research and ethics committee "EAREC", King Abdulaziz University.

\section{Consent for publication}

Not applicable

\section{Availability of data and materials}

Not applicable

\section{Competing interests}

No competing interests

\section{Funding}

There was no funding available for the current manuscript submitted.

\section{Authors' contributions}

All authors conceived and planned the experiments. MF carried out the implementation of the experiments. RM planned and carried out the statistical analyses and contributed to sample preparation. MF took the lead in writing the manuscript. HA, MY, MG, and SK contributed to the interpretation of the results, provided critical feedback, supervision and helped shape the research, analysis, and manuscript. 


\section{Acknowledgments}

I would like to express my sincere gratitude to my advisor Prof. Hekma Abdul Latif, for her continuous support of my researches, for her patience, motivation, and immense knowledge. I would like to thank the rest of my thesis committee: Assistant Prof. May Galal, Assistant Prof. Mohamed El yammany, for their, insightful comments. My sincere thanks also go to Dr. Iklas Sindi, Batterjee medical college, Jeddah, KSA for offering me the opportunities to work on this project in the college laboratories.

\section{References}

1. Koya D, Hayashi K, Kitada M, Kashiwagi A, Kikkawa R, Haneda M. Effects of antioxidants in diabetes-induced oxidative stress in the glomeruli of diabetic rats. J Am Soc Nephrol. 2003; 14:S250-S253.

2. Debnam ES and Unwin RJ. "Hyperglycemia and intestinal and renal glucose transport: implications for diabetic renal injury". Kidney Int 1996; 50:1101- 1109

3. Fridlyand LE and Philipson LH. "Oxidative reactive species in cell injury: mechanisms in diabetes mellitus and therapeutic approaches". Ann N Y Acad Sci 2005; 1066:136-15

4. Sevindik M. "Antioxidant activity of ethanol extract of Daedaleopsis nitida medicinal mushroom from Turkey". Mycopath 2018; 16: 47-49.

5. Sevindik, M. “Wild Edible Mushroom Cantharellus cibarius as a Natural Antioxidant Food." Turk J of Agric: Food Science and Technology 7 2019: 1377-1381.

6. Defronzo RA. Bromocriptine: a sympatholytic, d2-dopamine agonist for the treatment of type 2 diabetes [published correction appears in Diabetes Care. 2011;34:1442. Dosage error in article text]. Diabetes Care. 2011; 34(4):789-794. DOI:10.2337/dc11-0064

7. Shivaprasad C, Kalra S. Bromocriptine in type 2 diabetes mellitus. Indian J Endocrinol Metab. 2011; 15:S17-S24. DOI:10.4103/22308210.83058

8. Narkar V, Kunduzova O, Hussain T, Cambon C, Parini A, Lokhandwala M. Dopamine D2-like receptor agonist bromocriptine protects against ischemia/reperfusion injury in rat kidney. Kidney Int. 2004; 66:633-640. DOI:10.1111/j.1523-1755.2004.00783.x

9. Oliva Mejía-Rodríguez, Jorge E. Herrera-Abarca, Guillermo Ceballos-Reyes, Marcela Avila-Diaz, Carmen Prado-Uribe, Francisco Belio-Caro, Antonio Salinas-González, Helios Vega-Gomez, Cleto Alvarez-Aguilar, Bengt Lindholm, Elvia García-López, and Ramón Paniagua. "Cardiovascular and Renal Effects of Bromocriptine in Diabetic Patients with Stage 4 Chronic Kidney Disease," Biomed Res. Int, 2013, Article ID 104059. Doi.org/10.1155/2013/104059

10. Lahlou S, Duarte GP. Hypotensive action of bromocriptine in the DOCA-salt hypertensive rat: contribution of spinal dopamine receptors. Fundam Clin Pharmacol. 1998;12 :599-606. DOI:10.1111/j.1472-8206.1998.tb00992.x

11. Luchsinger A, Grilli M, Velasco M. Metoclopramide, and domperidone block the antihypertensive effect of bromocriptine in hypertensive patients. Am J Ther. 1998;5:81-88. DOI:10.1097/00045391-199803000-00005

12. M Mokhles., et al. "Dopamineagonist and heart failure in patients with Parkinson's disease: a nested case-control study on multiple health care databases". in Proceedings of the European Society of Cardiology Congress, Stockholm, Sweden, 2010.

13. Bordet R. [Central dopamine receptors: general considerations (Part 1)]. Rev Neurol (Paris). [Article in French]. 2004; 160:862-870.

14. Melmed S, Braunstein GD, Chang RJ, Becker DP. Pituitary tumors secreting growth hormone and prolactin. Ann. Intern. Med. 1986; 105:238-253.

15. Louis C.S. Tan, Kenneth K.C. Ng, Wing-Lok Au, Raymond K.K. Lee, Yiong-Huak Chan, Nigel C.K. Tan.Bromocriptine use and the risk of valvular heart disease. J Mov Disord 2009; 24: 344-349. org/10.1002/mds.22228

16. Wakil A, Rigby AS, Clark AL, Kallvikbacka-Bennett A, Atkin SL. Low dose cabergoline for hyperprolactinaemia is not associated with clinically significant valvular heart disease. Eur J Endocrinol. 2008;159: R11-R14. DOI:10.1530/EJE-08-0365

17. Kekewska A, Hübner H, Gmeiner P, Pertz HH. The bulky N6 substituent of cabergoline is responsible for agonism of this drug at 5hydroxytryptamine 5-HT2A and 5-HT2B receptors and thus is a determinant of valvular heart disease. J Pharmacol Exp Ther. 2011;338 :381-391. DOI:10.1124/jpet.111.181255

18. Oana F, Onozuka H, Tsuchioka A, et al. Function and expression differences between ergot and non-ergot dopamine D2 agonists on heart valve interstitial cells. J Heart Valve Dis. 2014; 23:246-252.

19. Brasil D, Temsah RM, Kumar K, Kumamoto H, Takeda N, Dhalla NS. Blockade of 5-HT(2A) receptors by sarpogrelate protects the heart against myocardial infarction in rats. J Cardiovasc Pharmacol Ther. 2002; 7 :53-59. DOI:10.1177/107424840200700i108

20. Satomura K, Takase B, Hamabe A, et al. Sarpogrelate, a specific 5HT2-receptor antagonist, improves the coronary microcirculation in coronary artery disease. Clin Cardiol. 2002; 25 :28-32. DOI:10.1002/clc.4950250108

Page $7 / 11$ 
21. Saini HK, Takeda N, Goyal RK, Kumamoto H, Arneja AS, Dhalla NS. Therapeutic potentials of sarpogrelate in cardiovascular disease. Cardiovasc Drug Rev. 2004; 22(1):27-54. doi:10.1111/j.1527-3466.2004.tb00130.x

22. Kanter M, Coskun O, Korkmaz A, Oter S. Effects of Nigella sativa on oxidative stress and beta-cell damage in streptozotocin-induced diabetic rats. Anat Rec A Discov Mol Cell Evol Biol. 2004; 279 :685-691. DOI:10.1002/ar.a.20056

23. Festing MF, Altman DG. Guidelines for the design and statistical analysis of experiments using laboratory animals. ILAR J 2002; 43:244-58.

24. Ribeiro-de-Oliveira A Jr, Guerra RM, Fóscolo RB, Marubayashi U, Reis AM, Coimbra CC. Effects of chronic bromocriptine (CB-154) treatment on the plasma glucose and insulin secretion response to neurocytoglucopenia in rats. J Endocrinol. 1999; 162(2):237-242. doi:10.1677/joe.0.1620237

25. Mayer J, Sato A, Kiupel M, DeCubellis J, Donnelly T. Extralabel use of cabergoline in the treatment of a pituitary adenoma in a rat [published correction appears in J Am Vet Med Assoc. 2011 Oct 15;239(8):1089]. J Am Vet Med Assoc. 2011;239(5):656-660. doi:10.2460/javma.239.5.656

26. Kim DH, Choi BH, Ku SK, Park JH, Oh E, Kwak MK. Beneficial Effects of Sarpogrelate and Rosuvastatin in High Fat Diet/StreptozotocinInduced Nephropathy in Mice. PLoS One. 2016;11(4):e0153965. Published 2016 Apr 20. doi:10.1371/journal.pone.0153965

27. Mukherjee KI. "Medical laboratory technology". Tata Mc Graw Hill. 1988; 3: 991-993

28. Johns C, Gavras I, Handy DE, Salomao A, Gavras H. Models of experimental hypertension in mice. Hypertension. 1996; $28(6): 1064-1069$. doi:10.1161/01.hyp.28.6.1064

29. King PRN and King EJ. "Estimation of plasma phosphatase by determination of hydrolyzed phenol with amino antipyrine". J Clin Path 1954; 7: 322326. doi: 10.1136/jcp.7.4.322

30. Lopez J. Carl A. Burtis, Edward R. Ashwood and David E. Bruns (eds): Tietz Textbook of Clinical Chemistry and Molecular Diagnosis (5th edition): Elsevier, St. Louis, USA, 2012, 2238 pp, 909 illustrations. ISBN: 978-1-4160-6164-9. Indian J Clin Biochem. 2013;28(1):104-105. doi:10.1007/s12291-012-0287-7

31. Kaplan A. "Urea nitrogen and urinary ammonia. In: Standard Method of Clinical Chemistry". Ed. Meites S. pp 245 - 256. Academic Press Inc., New York, 1965.

32. Nielands JB. "In Methods in Enzymology". p. 449. Ed. by Colowick, S. P. \& Kaplan, N. 0. New York: Academic Press Inc., 1955.

33. Fishbein MC, Meerbaum S, Rit J, Lando U, Kanmatsuse K, Mercier JC, Corday E, Ganz W. Early phase acute myocardial infarct size quantification: validation of the triphenyl tetrazolium chloride tissue enzyme staining technique. Am Heart J. 1981; 101(5):593-600. doi:10.1016/0002-8703(81)90226-x

34. Nachlas M and Schnitka T. "Macroscopic identification of early myocardial infarcts by alterations in dehydrogenase activity". Am.J.Pathol 1963; 42:379-406

35. Curtis, M. J., Bond, R. A., Spina, D., Ahluwalia, A., Alexander, S. P., Giembycz, M. A., Gilchrist, A., Hoyer, D., Insel, P. A., Izzo, A. A., Lawrence, A. J., MacEwan, D. J., Moon, L. D., Wonnacott, S., Weston, A. H., \& McGrath, J. C.. Experimental design and analysis and their reporting: new guidance for publication in BJP [published correction appears in Br J Pharmacol. 2015 Sep;172(18):4600]. Br J Pharmacol. 2015; 172(14):3461-3471. doi:10.1111/bph.12856

36. Defronzo RA. Bromocriptine: a sympatholytic, d2-dopamine agonist for the treatment of type 2 diabetes. Diabetes Care. 2011; 34:789794. doi:10.2337/dc11-0064

37. Scranton R, Cincotta A. Bromocriptine-unique formulation of a dopamine agonist for the treatment of type 2 diabetes. Expert Opin Pharmaco. 2010; 11:269-279. doi:10.1517/14656560903501544

38. Aminorroaya A, Janghorbani M, Ramezani M, Haghighi S, Amini M. Does bromocriptine improve glycemic control of obese type-2 diabetics?. Horm Res. 2004; 62:55-59. doi:10.1159/000078932

39. Zeng C, Zhang M, Asico LD, Eisner GM, Jose PA. The dopaminergic system in hypertension. Clin Sci (Lond). 2007; $112(12): 583-597$. doi:10.1042/CS20070018

40. McCoy CE, Douglas FL, Goldberg LI. Selective antagonism of the hypotensive effects of dopamine agonists in spontaneously hypertensive rats. Hypertension. 1986; 8(4):298-302. doi:10.1161/01.hyp.8.4.298

41. Konkalmatt, P. R., Asico, L. D., Zhang, Y., Yang, Y., Drachenberg, C., Zheng, X., Han, F., Jose, P. A., \& Armando, I. Renal rescue of dopamine D2 receptor function reverses renal injury and high blood pressure. JCl Insight. 2016; 1:e85888. doi:10.1172/jci.insight.85888

42. Nichols CD. Serotonin 5-HT(2A) Receptor Function as a Contributing Factor to Both Neuropsychiatric and Cardiovascular Diseases. Cardiovasc Psychiatry Neurol. 2009; 2009:475108. doi:10.1155/2009/475108

43. Fujita, M., Minamino, T., Sanada, S., Asanuma, H., Hirata, A., Ogita, H., Okada, K., Tsukamoto, O., Takashima, S., Tomoike, H., Node, K., Hori, M., \& Kitakaze, M.Selective blockade of serotonin 5-HT2A receptor increases coronary blood flow via augmented cardiac nitric oxide

Page $8 / 11$ 
release through 5-HT1B receptor in hypoperfused canine hearts. J Mol Cell Cardiol. 2004; 37:1219-1223.

doi:10.1016/j.yjmcc.2004.09.016

\section{Tables}

[able 1: Effect of the tested drugs on BGL in alloxan-induced diabetic rats.

\begin{tabular}{|c|c|c|c|c|}
\hline \multicolumn{5}{|c|}{ BGL mg/dL } \\
\hline Groups & week 1 & week 2 & week 3 & week 4 \\
\hline Normal control group & $136.5 \pm 18.52$ & $\begin{array}{l}121.33 \pm \\
12.08\end{array}$ & $\begin{array}{c}119.25 \pm \\
11.35\end{array}$ & $109 \pm 10.92$ \\
\hline Diabetic control group & $\begin{array}{c}359.75 \pm \\
45.13^{*}\end{array}$ & $328 \pm 141.34 *$ & $\begin{array}{l}428.5 \pm \\
121.17^{*}\end{array}$ & $396.5 \pm 80.60 *$ \\
\hline Diabetic group treated with Bromocriptine & $191 \pm 16.89^{\#}$ & $\begin{array}{c}199.25 \pm \\
65.05^{\#}\end{array}$ & $\begin{array}{c}238.25 \pm \\
56.88^{\#}\end{array}$ & $\begin{array}{c}284.25 \pm \\
148.00^{\#}\end{array}$ \\
\hline Diabetic group treated with Cabergoline & $\begin{array}{c}213.75 \pm \\
37.74^{\#}\end{array}$ & $\begin{array}{c}211.75 \pm \\
38.62^{\#}\end{array}$ & $293 \pm 213.15^{\#}$ & $\begin{array}{c}280.25 \pm \\
220.48^{\#}\end{array}$ \\
\hline Diabetic group treated with Sarpogrelate & $\begin{array}{l}326.25 \pm \\
93.45\end{array}$ & $\begin{array}{c}298.25 \pm \\
122.37\end{array}$ & $\begin{array}{c}393.75 \pm \\
118.77\end{array}$ & $369.75 \pm 43.15$ \\
\hline $\begin{array}{l}\text { Diabetic group treated with } \\
\text { +sarpogrelate }\end{array}$ & $\begin{array}{c}247.75 \pm \\
50.35^{\#}\end{array}$ & $\begin{array}{l}215.5 \pm \\
33.20^{\#}\end{array}$ & $\begin{array}{l}310.25 \pm \\
70.59^{\#}\end{array}$ & $\begin{array}{c}288.25 \pm \\
109.41^{\#}\end{array}$ \\
\hline $\begin{array}{lllll}\text { Diabetic group } & \text { treated } & \text { with } & \text { cabergoline } \\
\text { sarpogrelate }\end{array}$ & $196 \pm 54.20^{\#}$ & $\begin{array}{c}158.75 \pm \\
35.01^{\#}\end{array}$ & $\begin{array}{l}235.5 \pm \\
182.22^{\#}\end{array}$ & $\begin{array}{c}215.75 \pm \\
141.46^{\#}\end{array}$ \\
\hline
\end{tabular}

Talues shown are means \pm SEM; $\mathrm{n}=6$ rats per group. ${ }^{*} \mathrm{P}<0.05$, significantly different from normal control group; \# $\mathrm{P}<$ ).05, significantly different from diabetic control group.

Table 2: Effect of the tested drugs on Kidney Hypertrophic Index in alloxan-induced diabetic rats.

\begin{tabular}{|l|c|}
\hline \multicolumn{2}{|c|}{ Kidney Hypertrophic Index } \\
\hline Groups & KHI ( g/g * 1000 ) \\
\hline Normal control group & $4.555 \pm 0.423$ \\
\hline Diabetic control group & $6.6125 \pm 0.57^{*}$ \\
\hline Diabetic group treated with Bromocriptine & $4.7475 \pm 0.33^{\#}$ \\
\hline Diabetic group treated with Cabergoline & $4.81 \pm 0.49^{\#}$ \\
\hline Diabetic group treated with Sarpogrelate & $5.90 \pm 0.27$ \\
\hline Diabetic group treated with Bromocriptine + sarpogrelate & $4.715 \pm 0.61^{\#}$ \\
\hline Diabetic group treated with cabergoline + sarpogrelate & $4.46 \pm 0.48^{\#}$ \\
\hline
\end{tabular}

Values shown are means \pm SEM; $\mathrm{n}=6$ rats per group. $* \mathrm{P}<0.05$, significantly different from normal control group; \# P < 0.05, significantly different from diabetic control group.

able 3: Effect of the tested drugs on mean systolic blood pressure in alloxan-induced diabetic rats. 
Mean Systolic Blood Pressure MSBP (mmHg)

\begin{tabular}{|c|c|c|c|c|}
\hline roups & week 1 & week 2 & week 3 & week 4 \\
\hline ormal control group & $110 \pm 4.01$ & $118.25 \pm 8.99$ & $108.75 \pm 4.57$ & $111.5 \pm 4.20$ \\
\hline iabetic control group & $112.5 \pm 9.14$ & $\begin{array}{c}121.75 \pm \\
11.35\end{array}$ & $150.75 \pm 5.25^{*}$ & $151.25 \pm 5.12^{*}$ \\
\hline iabetic group treated with Bromocriptine & $115 \pm 9.12$ & $102.75 \pm 6.8$ & $109 \pm 10.23^{\#}$ & $\begin{array}{c}121.75 \pm \\
15.26^{\#}\end{array}$ \\
\hline iabetic group treated with Cabergoline & $103.75 \pm 7.0$ & $105.5 \pm 9.14$ & $123 \pm 7.87^{\#}$ & $\begin{array}{l}107.75 \pm \\
107.75^{\#}\end{array}$ \\
\hline iabetic group treated with Sarpogrelate & $\begin{array}{c}118.75 \pm \\
10.87\end{array}$ & $114.75 \pm 8.53$ & $137.75 \pm 8.53$ & $139 \pm 18.56$ \\
\hline $\begin{array}{llll}\text { iabetic group treated with } & \text { Bromocriptine } \\
\text { sarpogrelate }\end{array}$ & $104.5 \pm 7.59$ & $104.75 \pm 4.99$ & $\begin{array}{c}106.25 \pm \\
11.08^{\#}\end{array}$ & $118 \pm 13.03^{\#}$ \\
\hline $\begin{array}{l}\text { iabetic group treated with cabergoline }+ \\
\text { irpogrelate }\end{array}$ & $\begin{array}{l}109.25 \pm \\
11.58\end{array}$ & $105 \pm 9.05$ & $106 \pm 18.3^{\#}$ & $104.25 \pm 5.5^{\#}$ \\
\hline
\end{tabular}

alues shown are means $\pm \mathrm{SEM} ; \mathrm{n}=6$ rats per group. $* \mathrm{P}<0.05$, significantly different from normal control group; \# $<0.05$, significantly different from diabetic control group.

[able 4: Effect of the tested drugs on liver and kidney functions in alloxan-induced diabetic rats after 4 weeks.

BIOCHEMICALS

\begin{tabular}{|c|c|c|c|c|}
\hline roup & ALP(IU/L) & AST(IU/L) & $\begin{array}{c}\text { Urea } \\
(\mathrm{mmol} / \mathrm{L})\end{array}$ & $\begin{array}{l}\text { Creatinine } \\
(\mathrm{mmol} / \mathrm{L})\end{array}$ \\
\hline ormal control group & $60.85 \pm 8.77$ & $25.04 \pm 4.96$ & $43.38 \pm 4.77$ & $0.46 \pm 0.07$ \\
\hline iabetic control group & $89.05 \pm 10.44^{*}$ & $45.86 \pm 7.57 *$ & $75.81 \pm 18.85^{*}$ & $1.89 \pm 0.19 *$ \\
\hline iabetic group treated with Bromocriptine & $68.83 \pm 7.27^{\#}$ & $34.18 \pm 5.78^{\#}$ & $60.41 \pm 6.22^{\#}$ & $1.04 \pm 0.26^{\#}$ \\
\hline iabetic group treated with Cabergoline & $73.27 \pm 7.93^{\#}$ & $21.37 \pm 10.05^{\#}$ & $52.09 \pm 2.23^{\#}$ & $0.79 \pm 0.11^{\#}$ \\
\hline iabetic group treated with Sarpogrelate & $82.16 \pm 23.83$ & $41.47 \pm 10.02$ & $69.41 \pm 7.65$ & $1.68 \pm 0.25$ \\
\hline $\begin{array}{l}\text { iabetic group treated with } \\
\text { sarpogrelate }\end{array}$ & $64.8 \pm 7.21^{\#}$ & $31.03 \pm 6.44^{\#}$ & $44.4 \pm 8.23^{\#}$ & $1.26 \pm 0.25^{\#}$ \\
\hline $\begin{array}{lllll}\text { iabetic group treated } & \text { with } & \text { cabergoline }+ \\
\text { irpogrelate } & & & & \\
\end{array}$ & $73.44 \pm 6.68^{\#}$ & $33.79 \pm 11.18^{\#}$ & $51.16 \pm 10.43^{\#}$ & $1.33 \pm 0.21^{\#}$ \\
\hline
\end{tabular}

alues shown are means $\pm \mathrm{SEM} ; \mathrm{n}=6$ rats per group. $* \mathrm{P}<0.05$, significantly different from normal control group; $\neq \mathrm{P}<0.05$, significantly different from diabetic control group.

'able 5: Effect of the tested drugs on Lactate dehydrogenase-1 and TNF $\alpha 1$ in alloxan-induced diabetic rats.

\begin{tabular}{|c|c|c|}
\hline \multicolumn{3}{|l|}{ BIOCHEMICALS } \\
\hline Group & LDH (IU/L) & $\mathrm{TNF} \alpha 1(\mathrm{pg} / \mathrm{mL})$ \\
\hline Normal control group & $17.42 \pm 0.69$ & $06.12 \pm 0.45$ \\
\hline Diabetic control group & $18.50 \pm 1.53$ & $08.32 \pm 0.56$ \\
\hline Diabetic group treated with Bromocriptine & $40.50 \pm 10.69^{\#}$ & $36.56 \pm 2.32 \#$ \\
\hline Diabetic group treated with Cabergoline & $36.86 \pm 12.47^{\#}$ & $31.20 \pm 4.23 \#$ \\
\hline Diabetic group treated with Sarpogrelate & $19.55 \pm 2.20$ & $09.74 \pm 0.98$ \\
\hline Diabetic group treated with Bromocriptine +sarpogrelate & $27.75 \pm 3.91^{\mathrm{a}}$ & $14.84 \pm 1.23^{\text {a }}$ \\
\hline Diabetic group treated with cabergoline + sarpogrelate & $34.57 \pm 6.60 \mathrm{~b}$ & $08.59 \pm 0.76^{b}$ \\
\hline
\end{tabular}


Values shown are means $\pm \mathrm{SEM} ; \mathrm{n}=6$ rats per group. $\# \mathrm{P}<0.05$, significantly different from diabetic control group. a $\mathrm{P}<0.05$, significantly different from diabetic group treated with bromocriptine. $\mathrm{b} \quad \mathrm{P}<$ 0.05, significantly different from diabetic group treated with cabergoline.

Figures
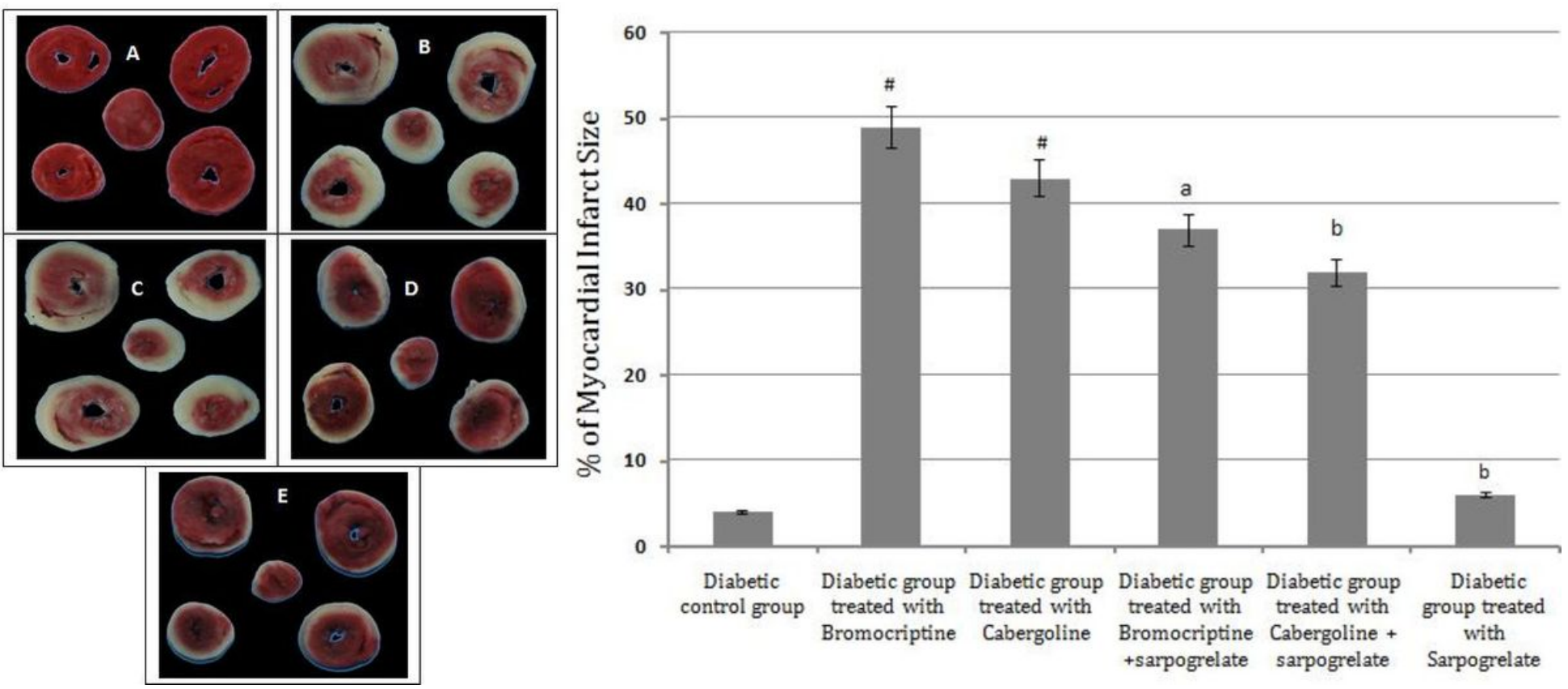

Figure 1

A: Effect of the tested drugs on the hearts in alloxan-induced diabetic mice after 4 weeks of treatment. Triphenyl Tetrazolium Chloride stained cross-section of the heart of (A) diabetic control rat showing uniform staining pattern. Both (B) Bromocriptine treated group, and (C) Cabergoline treated group showing a relative large pale, TTC negative area of infarct. Both (D) Bromocriptine+ Sarbogrelate treated group, and (E) Cabergoline+ Sarbogrelate treated group showing a relative small pale, TTC negative area of infarct. B: Effect of the tested drugs on percentage of myocardial infarct size in alloxan-induced diabetic rats. Values shown are means $\pm S E M ; n=6$ rats per group. \#P<0.05, significantly different from diabetic control group. a $\mathrm{P}<0.05$, significantly different from diabetic group treated with bromocriptine. $b \mathrm{P}<0.05$, significantly different from diabetic group treated with cabergoline 